\title{
Performance Evaluation and Economic Analysis of Developed Manual Mulch Laying Machine
}

\author{
Ashish Kumar Kerketta, Sheen C. Moses, Suryakanta Khandai* and Surendra Pal
}

Department of Farm Machinery and Power Engineering, VSAET, SHUATS, Allahabad, India

*Corresponding author

\section{A B S T R A C T}

\section{Keywords \\ Plastic mulch, \\ Manual, Field \\ capacity, Draft, \\ Theoretical, Actual \\ Article Info \\ Accepted: \\ 17 November 2018 \\ Available Online: \\ 10 December 2018}

Globally every year over 80,000 square $\mathrm{km}$ of agricultural lands are covered with plastic mulch films. These benefits lead to higher yields (by up to $100 \%$ for certain crops) in early duration crops (by upto one month) and in some case the ability to grow certain crop, which would not be possible without the mulch film. The performance of the newly developed manual mulching machine was evaluated. The average draft recorded $45.7 \mathrm{kgf}$ was at an angle of inclination of $35.50^{\circ}$ with speed of operation varies from 1.3 to 1.36 $\mathrm{km} / \mathrm{hr}$. The average power required for developed mulch laying machine was found to be $447.86 \mathrm{~N}$. The actual field capacity of mulch laying machine was found to be $0.113 \mathrm{ha} / \mathrm{h}$, whereas the theoretical field capacity was found to be $0.162 \mathrm{ha} / \mathrm{h}$. It was found that the actual field capacity of developed mulch laying machine varies by 0.1 in comparison to manually mulch laying.

\section{Introduction}

To make more effective mulching in agriculture can be done with plastic and since last 10 years, visible increase in plastic mulching is found in India. This plastic mulching helps in maintaining soil temperatures, proper weed management, moisture conservation, reduction of certain insect pests, high crop yields, improved germination rates and more efficient use of soil nutrients. According to Reynolds (2009), Globallyevery year over 80,000 square $\mathrm{km}$ of agricultural lands are covered with plastic mulch films. These benefits lead to higher yields (by up to $100 \%$ for certain crops) in early duration crops (by upto one month) and in some case the ability to grow certain crop, which would not be possible without the mulch film (Clarkson, 1957).

Plasticulture began in the 1950s and early 1960s with the introduction and use of plastic films, mulches, and drip irrigation systems (Maughan and Drost, 2016). They are used commercially for both vegetables and small fruit crops. Vegetable crops that are well suited to production with plastic mulch are typically high value row crops such as crops from the Solanaceae (tomato, eggplant, and pepper) and Cucurbitaceae (melons, watermelons, squash, cucumber) families, strawberries, green beans, asparagus, and salads, among others, have shown significant 
gains when cultivated with mulch (Witter and Castilla, 1995).The demand for mulching machine in India is increasing day by day. Most of the farming operation such as transplanting, harvesting, threshing is done by labour which is time consuming and costlier also and lastly they will not gain that much benefit as they wished or they deserved. So mulching machine is the best way to recover and redeveloped farming in different style. Traditional; manual mulching process characterized as labour intensive, poor quality of work, disturbances due to wind during laying of mulch sheet additionally causes problem of tearing of sheet during handling and most importantly difficulty in the covering of mulch sheet. Presently, for laying plastic mulch sheet manually around 4-5 labours are required. Power operated machine is effective but not economical for small farmers and it requires larger field, uniformity in the topography, needed road facility to reach the machinery in the field as well as high powered tractor is required to operate the machine. Keeping this consideration newly developed manual mulching machine is tested for calculation of the efficiency and cost analysis. The performance of the mulching machine was evaluated.

\section{Materials and Methods}

The Development of manual plastic mulch laying machine was designed as a functional and experimental unit. The design of machine components was based on the principles of operations and field tests. It was compared with the traditionalmethod, to give a correct shape in form of prototype. The mechanical design details were also given with due attention so that it gave adequate functional rigidity for the design of machine.

\section{Economical consideration}

The cost of the mulch laying machine should be as low as possible so, that small farmers can afford to purchase the machine.

The material of construction of different components should be easily and locally available.

\section{Cost calculation}

\section{Cost of operation $=$ Fixed cost + Variable cost}

Fixed cost: Depreciation: $\mathrm{D}=\mathrm{C}-\mathrm{S}$

Where: $\mathrm{C}=$ initial cost

$\mathrm{S}=10 \%$ of $\mathrm{C}, \mathrm{L}=6$ years, $\mathrm{H}=300(\mathrm{hr} / \mathrm{yr})$

\section{Interest}

$\mathrm{I}=\frac{\mathrm{C}+\mathrm{S} \times \mathrm{i}}{2 \times \mathrm{H}}$

\section{Housing tax+insurance@1\% of each C Repair and maintenance @ $10 \%$ of $\mathrm{C}$ variable cost}

Wages of operator@250 rupees per day

Total operational cost $=$ fixed + variable

Cost of plastic mulch laying=time taken xoperational cost per hour

Total cost of plastic sheet laying=time $\times$ cost per hour

\section{Power requirement}

Calculation of power is needed to determine the efficient use of manual power. A man can produce power equal to $0.1 \mathrm{hp}$. It was the power required to operate the machine by a person with an average pulling force and speed. It was calculated by using the formula.

$$
\text { Power }(\mathrm{hp})=\frac{\text { Pulling force }(\mathrm{kg}) \times \text { Speed }(\mathrm{m} / \mathrm{s})}{75}
$$




\section{Field capacity}

Theoretical field capacity was measured as per following formula (Bainer et al., 1960):

Theoretical Field capacity $(\mathrm{ha} / \mathrm{h})=\frac{\mathrm{W} \times \mathrm{S}}{10}$ Where,

$\mathrm{W}=$ Effective width of implement, $\mathrm{m}$; and $\mathrm{S}=$ Speed of operation, $\mathrm{km} / \mathrm{h}$.

Actual field capacity was measured by taking an area of $10 \times 10$ square meter i.e. and measuring the time in actual field condition. It includes turning loss, filling time and break down time also.

\section{Field efficiency}

From the actual and theoretical field capacity, the field efficiency was calculated (Bainer et al., 1960),

Field efficiency $(\%)=\frac{\text { AFC }}{\text { TFC }} \times 100$

Where,

$\mathrm{FE}=$ Field efficiency $(\%)$;

$\mathrm{AFC}=$ Actual field capacity $(\mathrm{ha} / \mathrm{h})$; and

$\mathrm{TFC}=$ Theoretical field capacity $(\mathrm{ha} / \mathrm{h})$.

The data were recorded for all three mulching methods under actual field conditions and also compared (Michael and Ojha, 2003).

\section{Energy input}

$\mathrm{H}=\mathrm{t} \times \mathrm{e}$

$\mathrm{H}=$ human energy input = time taken by human

$\mathrm{e}=$ energy coefficient for male is 1.96 for female is 1.56

\section{Results and Discussion}

The performance of the manual plastic mulch laying machine was evaluated along with its comparative performance evaluation with manually mulch laying method was done. The cost economics and energy requirement of the developed machine was also calculated.

\section{Speed of operation}

The average speed of operation was found $1.65 \mathrm{~km} / \mathrm{h}$.

The average speed of operation for mulching operation was found to be $1.65 \mathrm{~km} / \mathrm{h}$, respectively, for a distance of $10 \mathrm{~m}$ (Table 1 ).

\section{Measurement of draft}

The spring balance was hitched between the handle and the machines frames beam during the operation. The pulling force varied from minimum 4.0 to maximum $4.2 \mathrm{~kg}$ at $45^{\circ}$ angle of inclination. The draft accordingly computed varied from $28.0 \mathrm{kgf}$ to $29.4 \mathrm{kgf}$. The average draft recorded was $28.7 \mathrm{kgf}$ (Table 2).

\section{Power requirement}

The average power required for mulching was found to be $0.0249 \mathrm{hp}$ for which may be operated by men with average output of $0.1 \mathrm{hp}$ (Table 3).

\section{Physiological response}

During the field perform evaluation, the human physiological response was measured by the equipment and recorded the data in data sheet (Table 4).

\section{Cost calculation of manually operated mulching machine}

The economic evaluation of the developed machine is also necessary for adopt it. After developed the machine we did a field work with it and evaluate it on the basis of required cost for work (Table 5). 


\section{Cost comparison of tractor operated mulching machine}

Cost of operation is the very important factor to judge the performing the same operation.

Thus in order to compare the economics of the tractor, MB Plough and sugarcane of operation was calculated (Table 6).

\section{Field efficiency}

The field efficiency was calculated for mulch using standard method as in Table 7. The average actual field capacity was found 0.166 $\mathrm{h} a / \mathrm{h}$, whereas the average theoretical field capacity was found to be $0.15 \mathrm{ha} / \mathrm{h}$. From the actual and theoretical field capacity the average field efficiency of the machine was found to be $80 \%$.

Table.1 Speed of operation

\begin{tabular}{|c|c|c|c|}
\hline Sr.no. & distance(m) & time(s) & speed(km/h) \\
\hline $\mathbf{1}$ & 10 & 22 & 1.63 \\
\hline $\mathbf{2}$ & 10 & 21 & 1.71 \\
\hline $\mathbf{3}$ & 10 & 22 & 1.63 \\
\hline Average & 10 & 21.66 & 1.65 \\
\hline
\end{tabular}

Table.2 Draft required for manually operated mulching machine

\begin{tabular}{|c|c|c|c|}
\hline Sr.no. & pull(kg) & angle of inclination (degrees) & draft(kgf) \\
\hline $\mathbf{1}$ & 41 & 45 & 28.7 \\
\hline $\mathbf{2}$ & 40 & 45 & 28.0 \\
\hline $\mathbf{3}$ & 42 & 45 & 29.0 \\
\hline Average & 41 & 45 & 28.7 \\
\hline
\end{tabular}

Table.3 Power requirement for the mulching machine

\begin{tabular}{|c|c|c|c|}
\hline Sr.no. & $\begin{array}{c}\text { speed of operation } \\
(\mathbf{k m} / \mathbf{h})\end{array}$ & draft $(\mathbf{k g f})$ & Hp \\
\hline $\mathbf{1}$ & 1.63 & 28.7 & 0.0246 \\
\hline $\mathbf{2}$ & 1.71 & 28.0 & 0.0250 \\
\hline $\mathbf{3}$ & 1.63 & 29.4 & 0.0252 \\
\hline Average & 1.65 & 28.7 & 0.0249 \\
\hline
\end{tabular}

Table.4 Physiological response

\begin{tabular}{|c|c|c|c|c|c|c|c|}
\hline Subject & \multicolumn{2}{|c|}{ Standard } & \multicolumn{2}{c|}{ Initial } & \multicolumn{2}{c|}{ Final } & \\
& $\begin{array}{c}\text { Pulse rate } \\
\text { b/m }\end{array}$ & Blood pressure & $\begin{array}{c}\text { pulse } \\
\text { rate }\end{array}$ & $\begin{array}{c}\text { blood } \\
\text { pressure }\end{array}$ & $\begin{array}{c}\text { pulse } \\
\text { rate }\end{array}$ & $\begin{array}{c}\text { blood } \\
\text { pressure }\end{array}$ & Time(sec) \\
\hline S1 & 72 & $120 / 80-140 / 90$ & 76 & $109 / 64$ & 148 & $121 / 77$ & 22 \\
\hline S2 & 72 & $120 / 80-140 / 90$ & 102 & $124 / 84$ & 149 & $125 / 88$ & 21 \\
\hline S3 & 72 & $120 / 80-140 / 90$ & 80 & $119 / 79$ & 94 & $129 / 72$ & 22 \\
\hline
\end{tabular}


Table.5 Calculation of manually operated mulching machine

\begin{tabular}{|l|l|}
\hline Depreciation cost (Rs/hr) & 1.75 \\
\hline Interest (Rs/hr) & 0.64 \\
\hline Housing + tax + insurance @ 1\% of C (Rs/hr) & 0.35 \\
\hline Repair and maintenance @ 10\% of C (Rs/hr) & 1.16 \\
\hline Wager of operator (Rs/hr) & 31.25 \\
\hline Total operation cost (Rs/hr) & 35.15 \\
\hline Time taken to cover 1 ha. Field (hr) & 6.06 \\
\hline Field capacity (ha/hr) & 0.165 \\
\hline Cost of plastic laying for single men (Rs/hr) & 213.00 \\
\hline Total cost of plastic laying for 2 men $(\mathrm{Rs} / \mathrm{hr})$ & 625.00 \\
\hline
\end{tabular}

Table.6 Cost of operation

\begin{tabular}{|l|lcc|}
\hline Assumptions & Tractor & Mb plough & Sugarcane \\
a) Initial cost $(\mathrm{C})$ & 500000 & 18000 & 100000 \\
b) Salvage Cost $(10 \%$ of $\mathrm{C})$ & 50000 & 1800 & 10000 \\
c) Life (YEARS) & 10 & 10 & \\
d) No. of useful working hours(H) & - & & \\
e) Interest rate per year( $\left.\mathrm{I}_{\mathrm{r}}\right)$ & - & & \\
\hline Fixed Cost (per hour) & Tractor & Mb Plough & Sugarcane \\
a) Depreciation (D) & 45 & 54 & 45 \\
b) Interest $\left(\mathrm{I}_{\mathrm{r}}\right)$ & 33 & 3.96 & 33 \\
c) Insurance and taxes, housing@3\% & 15 & 18.72 & 15 \\
\hline
\end{tabular}

Table.7 Field efficiency

\begin{tabular}{|c|c|c|c|c|}
\hline Subject & speed(km/h) & $\begin{array}{c}\text { Theoretical field capacity } \\
\text { (ha/hr) }\end{array}$ & $\begin{array}{c}\text { Actual field capacity } \\
\text { (ha/hr) }\end{array}$ & $\begin{array}{c}\text { Field efficiency } \\
\%\end{array}$ \\
\hline S1 & 1 & 0.1 & 0.163 & 85 \\
\hline S2 & 1.5 & 0.15 & 0.171 & 80 \\
\hline S3 & 2 & 0.2 & 0.163 & 75 \\
\hline Average & 1.5 & 0.15 & 0.166 & 80 \\
\hline
\end{tabular}

Field efficiency

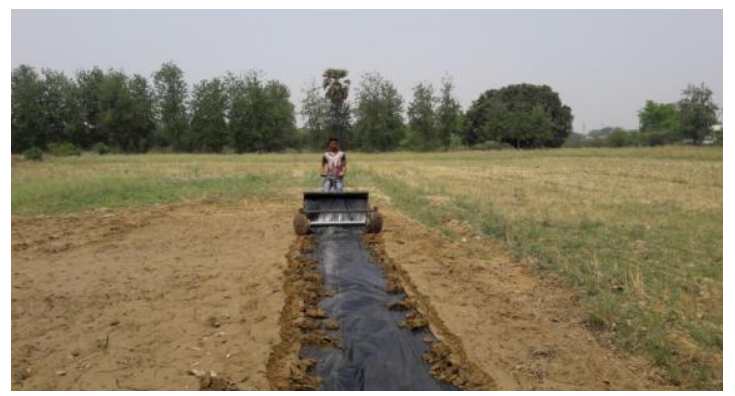


From the above test the performance of manual mulch machine was evaluated and the final conclusion is as follows.

The speed of operation was found to vary from 1.33 to $1.36 \mathrm{~km} / \mathrm{h}$. The average speed of operation of developed mulch laying machine for laying of plastic sheet was found to be $1.35 \mathrm{~km} / \mathrm{h}$ for a distance of $30 \mathrm{~m}$.

The average power required for developed mulch laying machine was found to be $0.162 \mathrm{~kW}(0.22 \mathrm{hp})$, which may be operated by a pair of bullocks with average output of 0.50 hp.

The major conclusions drawn from the present study are specified below.

The average draft recorded $45.7 \mathrm{kgf}$ was at an angle of inclination of $35.50^{\circ}$ with speed of operation varies from 1.3 to $1.36 \mathrm{~km} / \mathrm{hr}$.

The average power required for developed mulch laying machine was found to be 447.86 N.

The actual field capacity of mulch laying machine was found to be $0.113 \mathrm{ha} / \mathrm{h}$, whereas the theoretical field capacity was found to be $0.162 \mathrm{ha} / \mathrm{h}$.

It was found that the actual field capacity of developed mulch laying machine varies by 0.1 in comparison to manually mulch lying.

\section{References}

1. Bainer, R., Kepner, R. A. and Barger, E. L., 1987. Principles of farm machinery. C.S.B. Publishers and distributor, New Delhi.

2. Maughan and Drost, 2016. Use of plastic mulch for vegetable production. Extension.usu.edu. USDA. Minto, J., 2016.

3. Evaluation of plastic mulch for mechanical installation, Degradation and moisture distribution pattern under onion.

4. Writer, S. H. and Castilla, N., 1995. Protected cultivation of horticultural crops worldwide. Hort Technology 5: 6-23.

\section{How to cite this article:}

Ashish Kumar Kerketta, Sheen C. Moses, Suryakanta Khandai and Surendra Pal. 2018. Performance evaluation and Economic Analysis of developed Manual Mulch Laying Machine. Int.J.Curr.Microbiol.App.Sci. 7(12): 2482-2487. doi: https://doi.org/10.20546/ijcmas.2018.712.282 